\title{
ПРОЦЕССУАЛЬНЫЕ ОСОБЕННОСТИ РАССМОТРЕНИЯ ДЕЛ ОБ УСТАНОВЛЕНИИ ПРОИСХОЖДЕНИЯ ДЕТЕЙ
}

\author{
(c) 2019 Хасимова Лейсан Нафисовна \\ кандидат юридических наук, доцент \\ Набережночелнинский институт Казанского федерального университета \\ 423800, РТ, г. Набережные Челны, пр-т Сююмбике, д. 10 \\ E-mail: hasimov_l@mail.ru \\ (c) 2019 Ющенко Наталья Анатольевна \\ кандидат юридических наук, доцент \\ Набережночелнинский институт Казанского федерального университета \\ 423800, РТ, г. Набережные Челны, пр-т Сююмбике, д. 10 \\ E-mail: yushchenko31@rambler.ru
}

Правовое регулирование отношений по поводу установления и оспаривания происхождения детей, требует дальнейшего исследования и совершенствования. Немаловажную роль играет и процессуальный аспект рассматриваемого вопроса.

На основе анализа действующего семейного законодательства РФ, базируясь на теоретических положениях, посвященных правовому регулированию установления происхождения детей, в статье исследуются процессуальные особенности рассмотрения дел об установлении происхождения детей и возникающие при этом проблемы.

Ключевые слова: происхождение ребенка, установление происхождения детей, судебный порядок установления происхождения детей.

Рождение человека - это событие, которое, кроме эмоционального содержания, имеет правовые последствия. Родители новорожденного приобретают особый правовой статус отца и матери по отношению к своему ребенку. При этом не имеет значения, какой характер носят сложившиеся между мужчиной и женщиной брачные отношения: законный или фактический.

На современном этапе развития общественных отношений, на фоне происходящих социальных изменений в обществе, либерализации семейных ценностей наблюдается кризис традиционной семьи. Все большее распространение приобретают различные формы фактических браков, растет число детей, рожденных вне брака. Это связано и с ослаблением социальной роли материнства и отцовства в сознании современных родителей.

Правовой статус ребенка формируется установлением его происхождения способами, определенными законом, что, в свою очередь, призвано порождать личные и имущественные права ребенка.

Дети во всем мире являются не только внутригосударственной, но и общечеловеческой ценностью. Это особая, социально-демографи- ческая группа, имеющая свои собственные интересы, нуждающаяся в специальной заботе общества и государства [2]. Вопросы защиты жизни, здоровья, благополучия несовершеннолетних являются приоритетными на современном этапе развития России. Однако проблема защиты прав ребенка сегодня до конца не решена.

Основные права ребенка, такие как знать своих родителей, право на заботу со стороны своих родителей, закреплены в ст. 7 Конвенции $\mathrm{OOH}$ «O правах ребенка». Неоспоримым является тот факт, что полноценная реализация основных прав несовершеннолетних возможна только в полной семье, при участии обоих родителей. Именно в такой семье, с большей долей вероятности возможно создание благоприятных условий для становления и развития гармоничной личности ребенка.

Семья выступает в качестве основного звена в процессе социализации ребенка. Однако отечественный законодатель не формулирует понятие семьи, легальное определение отсутствует.

На современном этапе развития цивилизации все чаще наблюдается тенденция к умалению значения традиционной модели семьи, к искажению семейных ценностей. Это влечет за 
собой увеличение числа разводов, замену зарегистрированных браков фактическими брачными отношениями. Как следствие, большое количество детей рождается вне брака.

Во многих государствах все большее распространение получают однополые браки. Вышеназванная тенденция влечет потребность в новых моделях взаимодействия родителей и детей.

Современное российское семейное законодательство в качестве основания возникновения многочисленных взаимных прав и обязанностей родителей и детей устанавливает юридическое оформление происхождения детей, удостоверенное в соответствии с законом. Такое удостоверение, в свою очередь, является и гарантией защиты прав ребенка, детства и материнства.

Современное отечественное семейное законодательство определяет порядок установления происхождения ребенка от его родителей. Установление происхождения ребенка от конкретной матери обычно проблем не вызывает и осуществляется органом ЗАГС на основании документов, выданных медицинским учреждением, в котором родился ребенок. Если же ребенок родился за пределами медицинского учреждения, то материнство может быть установлено на основании медицинской документации, показаний свидетелей или при наличии иных доказательств. Семейное законодательство регулирует вопросы установления материнства при рождении ребенка при помощи вспомогательных репродуктивных технологий.

Порядок установления отцовства зависит от того, состоят ли родители ребенка в браке. Если родители ребенка состоят в браке, то происхождение ребенка от отца устанавливается в административном порядке в органах записи актов гражданского состояния. Если же родители ребенка состоят в фактических брачных правоотношениях, то отцовство устанавливается в судебном порядке.

Как ранее было отмечено, гражданским процессуальным законодательством предусмотрено два вида судопроизводства, в которых возможно установление происхождения ребенка от конкретного лица.

Во-первых, исковое производство. Исковое производство возбуждается на основании подачи искового заявления в суд. Установление отцовства происходит в порядке искового производства в том случае, если между сторонами существует спор.
Во-вторых, особое производство. Если спор между сторонами отсутствует, суд вправе рассмотреть дело в порядке особого судопроизводства. Как правило, в таком порядке устанавливаются юридически значимые факты, в частности, факт отцовства (родственные отношения), факт регистрации рождения и факт признания отцовства.

Разграничение этих категорий дел происходит в зависимости от того жив ли отец ребенка и от того когда ребенок родился: до или после смерти предполагаемого отца. Представляется, что, помимо указанных оснований, следует назвать еще одно - наличие либо отсутствие спора о праве. Последнее основание влияет на возможность рассмотрения дела в порядке особого судопроизводства [3].

ГПК РФ устанавливает, что в содержании заявления об установлении факта, имеющего юридическое значение обязательно должна указываться цель, с которой устанавливается данный факт.

Например, отцовство часто устанавливается для получения возможности вступить в наследство. Также, факт признания отцовства требуется для внесения изменений в книгу записи актов гражданского состояния, а в последующем и в свидетельство о рождении ребенка и др.

Невозможность рассмотрения таких дел в административном порядке и отнесение их к подведомственности суда определяется несколькими факторами: во-первых, появлением на свет ребенка у лиц, чей брак не зарегистрирован; во-вторых, несогласием фактического отца признать отцовство в добровольном порядке; в-третьих, отказом органов опеки и попечительства дать согласие отцу ребенка на установление отцовства в административном порядке в случае смерти матери и других случаях, предусмотренных СК РФ; в-четвертых, заявлением матери об оспаривании отцовства; в-пятых, смертью фактического отца.

П. 3 ст. 29 ГПК РФ для дел об установлении отцовства предусматривает альтернативную подсудность, т.е. предоставляет истцу право выбора, в какой суд (по месту нахождения истца, или по месту нахождения ответчика) подавать документы. Подсудность для дел об установлении факта признания отцовства определяется местом жительства заявителей согласно ст. 266 ГПК РФ, то есть является исключительной.

За государственную регистрацию установ- 
ления факта признания отцовства, как за совершение уполномоченными государственными органами юридически значимого действия, Налоговым кодексом РФ предусмотрена государственная пошлина, она имеет фиксированный размер, который составляет 300 рублей.

На стадии возбуждения дела важно определить круг лиц, обладающих правом обратиться в суд с требованием об установлении отцовства, факта признания отцовства.

Законодатель называет круг лиц, имеющих право предъявлять требования об установлении отцовства: один из родителей, несовершеннолетняя мать по достижению 14 лет, опекун (попечитель), фактический воспитатель несовершеннолетнего, сам ребенок по достижении совершеннолетия, прокурор, орган опеки и попечительства.

Мать ребенка, опекун (попечитель), фактический воспитатель, а также сам ребенок по достижении им совершеннолетия вправе выступать в качестве заявителей по делам об установлении факта признания отцовства.

Решение суда по заявлению о признании факта отцовства устанавливает факт, имеющий юридическое значение. На основании такого решения в книгу записи актов гражданского состояния вносятся сведения об отце ребенка, и выдается свидетельство о рождении.

Следовательно, можно сказать, что правовым последствием признания судом факта отцовства является установление юридической связи между умершим отцом ребенка и самим ребенком, порождающей правоотношения особого рода [1].

После возбуждения дела, судом решается вопрос о составе лиц, участвующих в деле. Стоит отметить, что родители, являются законными представителями несовершеннолетнего. Для представления интересов ребенка родителем не требуется наличие доверенности. К участию в деле могут быть привлечены органы опеки и попечительства, прокурор, представители образовательных учреждений. Лицу, обратившемуся в суд с заявлением, присваивается процессуальный статус истца или заявителя, противоположной стороне - статус ответчика.

На стадии подготовки к разбирательству определяются доказательства, которые необходимо предоставить в судебном разбирательстве по существу.

Судья, как правило, вызывает мать и пред- полагаемого отца для опроса, по просьбе сторон могут быть истребованы доказательства, которые стороны не могут предоставить самостоятельно. В ходе подготовки дела к разбирательству судье необходимо определить и норму, подлежащую применению в каждом конкретном случае. От этого зависит круг обстоятельств, подлежащих выяснению в судебном разбирательстве.

В СК РФ не установлен срок исковой давности по делам данной категории, из чего можно сделать вывод о том, что факт признания отцовства может быть установлен судом в любое время после рождения ребенка.

СК РФ допускает установление происхождения детей, родившихся до 1 октября 1968 г. от лиц, не состоявших в браке между собой. При необходимости суд вправе установить факт признания отцовства в случае смерти лица, которое признавало себя отцом ребенка, если ребенок находился на иждивении этого лица к моменту его смерти либо ранее.

Сбор доказательств, как правило, производится на стадии подготовки дела к судебному разбирательству. Доказательства для установления отцовства в судебном порядке, предусмотренные ст. 49 СК РФ, существенно отличаются от тех, которые предусмотрены ст. 48 КоБС РСФСР. По смыслу ст. 48 КоБС они делятся на три группы: совместное проживание и ведение общего хозяйства; участие фактического отца ребенка в его воспитании либо содержании; признание ответчиком отцовства. Под совместным проживанием понимается проживание отца и матери ребенка в одном жилом помещении, совместное питание, взаимная забота друг о друге, приобретение имущества для совместного пользования и т.д. Ведение общего хозяйства подразумевает наличие общего семейного бюджета, средства которого расходуются на удовлетворение бытовых потребностей всех членов семьи (например, расходы на питание, одежду, благоустройство и т.д.).

Действующий СК РФ не рассматривает данные обстоятельства отдельно. Судом будут изучены все доказательства происхождения ребенка от конкретного отца. В качестве таковых могут исследоваться следующие доказательства: заключение генетической экспертизы, свидетельство о рождении ребенка; сожительство родителей ребенка без регистрации брака; квитанции о денежных переводах на содержание 
ребенка; свидетельские показания и т.д.

Однако, как установлено п. 2 ст. 67 ГПК РФ, ни одно из доказательств не имеет для суда заранее установленной силы. С другой стороны, любые доказательства, бесспорно свидетельствующие о происхождении ребенка от конкретного лица, служат основанием для удовлетворения иска.

Определенные правовые проблемы возникают при установлении происхождения детей, рожденных с применением вспомогательных репродуктивных технологий (ВРТ). Так, если ребенок родился при помощи метода ВРТ, то в качестве родителей новорожденного будут зарегистрированы лица, состоящие в браке и давшие согласие на применение искусственного оплодотворения или имплантацию эмбриона.

В соответствии с позицией Верховного Суда Российской Федерации между ребенком, рожденным при использовании донорского материала и донором, не возникает родительских правоотношений. При оспаривании и (или) установлении материнства или отцовства, донор не вправе ссылаться на то, что он является биологическим родителем ребенка.

Однако подобное правовое регулирование представляется недостаточным, так как порождает определенные правовые пробелы. В частности, нет однозначного ответа на вопрос о том, может ли оспаривать отцовство муж, давший согласие жене на зачатие ребенка путем опло- дотворения ее яйцеклетки донорским материалом, в том случае, когда такое согласие не имеет юридической силы в виду порока воли или по другим основаниям. Так, например, ст. 311-320 Гражданского Кодекса Франции предусматривают такую возможность [4].

Более того, многие государства выступают против развития методов ВРТ, рассматривая биологическое родство ребенка с родителями как единственное основание установления его происхождения. В законодательстве многих государств, членов ЕС, вообще не содержится правовых норм, регулирующих данные правоотношения [5].

Не смотря на неоднозначное отношение мирового сообщества к применению методов искусственной репродукции человека, наблюдается общемировая тенденция к изменению естественно-биологического статуса родителей на статус социальный [6]. Возникает так называемая новая концепция родства, где в центре угла рассматривается намерение человека стать родителем с применением методов вспомогательной репродукции. Данное намерение - один из важнейших аспектов для признания отцовство мужчины, не имеющего генетического родства с ребенком, а также для установления отцовства и материнства лиц, являющихся сторонами договора о суррогатном материнстве [7].

\section{Библиографический список}

1. Беспалов Ю.Ф. Разбирательство дел об установлении отцовства / Ю.Ф. Беспалов// Российская юстиция.2000. - № 6. - С. 27-29.

2. Худякова О.Ю. Установление происхождения детей по законодательству РФ и США: сравнительное исследование: автореф. дис. .... канд юрид. наук / О.Ю Худякова; Рос.гос соц.ун-т. - Москва, 2009. - 200 с.

3. Черных И.И. Особенности рассмотрения в суде дел об оспаривании отцовства (материнства) в правоотношениях суррогатного материнства / И.И. Черных // Законы России: опыт, анализ, практика. - 2017. - № 9. // Электрон. дан.- СПС «Гарант».

4. Corral H.F. Filiation and assisted reproductive technology // Trabajo publicado en Revue Générale de Droit (U. de Ottawa). 2001. No 31. P. 701-729.

5. Cfr. Rubellin-Devichi J. Droit de la Famille. Dalloz. 1996. No 1325. P. 410.

6. Cfr. Cirillo $F$. La fecondazione artificiale eterologa de il rapporto di paternità nella filiazione legittima de in quella natural. In Rivista di Diritto Civile. 1998. Vol. 44. P. 665.

7. Todorova V. Recognition of parental responsibility: biological parenthood v. legal parenthood, i.e. mutual recognition of surrogacy agreements: What is the current situation in the MS? Need for EU action? Brussels, 2010. P. 10. 